\title{
DETERMINANTS OF WEIGHT REGAIN AFTER BARIATRIC SURGERY
}

\author{
Fatores determinantes do reganho ponderal no pós-operatório de cirurgia bariátrica \\ Emanuelle Cristina Lins BASTOS ${ }^{1}$, Emília Maria Wanderley Gusmão BARBOSA ${ }^{1}$, Graziele Moreira Silva \\ SORIANO ${ }^{1}$, Ewerton Amorim dos SANTOS ${ }^{1}$, Sandra Mary Lima VASCONCELOS ${ }^{2}$
}

From ${ }^{1}$ Hospital Universitário Professor Alberto Antunes and ${ }^{2}$ Universidade Federal de Alagoas, Maceió, AL, Brazil

HEADINGS - Gastric bypass. Bariatric surgery. Weight gain.
ABSTRACT- Background - Bariatric surgery leads to an average loss of $60-75 \%$ of excess body weight with maximum weight loss in the period between 18 and 24 months postoperatively. However, several studies show that weight is regained from two years of operation. Aim: To identify the determinants of weight regain in post-bariatric surgery users. Methods: Prospective cross-sectional study with 64 patients who underwent bariatric surgery with postoperative time $\geq 2$ years valued at significant weight regain. The variables analyzed were age, sex, education, socioeconomic status, work activity related to food, time after surgery, BMI, percentage of excess weight loss, weight gain, attendance monitoring nutrition, lifestyle, eating habits, self-perception of appetite, daily use of nutritional supplements and quality of life. Results: There were 57 (89\%) women and 7 (11\%) men, aged $41.76 \pm 7.93$ years and mean postoperative period of $53.4 \pm 18.4$ months. The average weight and BMI were respectively $127.48 \pm 24.2 \mathrm{~kg}$ and $49.56 \pm 6.7 \mathrm{~kg} / \mathrm{m} 2$ at surgery. The minimum weight and BMI were achieved $73.0 \pm 18.6 \mathrm{~kg}$ and $28.3 \pm 5.5 \mathrm{~kg} / \mathrm{m} 2$, reached in $23.7 \pm 12$ months postoperatively. Regained significant weight occurred in 18 (28.1\%) cases. The mean postoperative period of $66 \pm 8.3$ months and work activities related to food showed statistical significance $(p=000$ and $p=0.003)$ for the regained weight. Conclusion: Bariatric surgery promotes adequate reduction of excess body weight, with significant weight regain observed after five years; post-operative time and work activity related to eating out as determining factors for the occurrence of weight regain.

\section{Correspondence:}

Emanuelle Cristina Lins Bastos

E-mail: manuclins@hotmail.com

Financial source: none

Conflicts of interest: none

Received for publication: 15/01/2013

Accepted for publication: 11/03/2013

DESCRTORES - Bypass gástrico. Cirurgia bariátrica. Ganho de peso.
RESUMO - Racional: A cirurgia bariátrica induz a uma média de perda de 60 a $75 \%$ do excesso de peso corporal, com máxima perda ponderal no período entre 18 e 24 meses de pós-operatório. Entretanto, vários estudos evidenciam que reganho ponderal ocorre a partir de dois anos da operação. Objetivo: Identificar fatores determinantes de reganho ponderal em usuários submetidos à cirurgia bariátrica. Métodos: Estudo transversal prospectivo com 64 indivíduos submetidos à cirurgia bariátrica com tempo de pósoperatório $\geq$ dois anos avaliados segundo o reganho de peso. As variáveis analisadas foram idade, sexo, escolaridade, classe econômica, atividade laboral relacionada à alimentação, tempo de pós-operatório, IMC, percentual de perda do excesso de peso, evolução ponderal, assiduidade no acompanhamento nutricional, estilo de vida, hábitos alimentares, auto-percepção do apetite, uso diário de suplementos nutricionais e qualidade de vida. Resultados: Foram 57 (89\%) mulheres e 7 (11\%) homens, com idade de $41,76 \pm 7,93$ anos e tempo médio de pós-operatório de $53,4 \pm 18,4$ meses. O peso e IMC médios foram, respectivamente, $127,48 \pm 24,2 \mathrm{~kg}$ e 49,56 $\pm 6,7 \mathrm{~kg} / \mathrm{m} 2$ no momento da operação. O peso e o IMC mínimos atingidos foram $73,0 \pm 18,6 \mathrm{~kg}$ e $28,3 \pm 5,5 \mathrm{~kg} /$ $\mathrm{m} 2$, alcançados em $23,7 \pm 12$ meses de pós-operatório. Reganho ponderal significativo ocorreu em 18 (28,1\%) casos. O tempo médio de pós-operatório de 66 $\pm 8,3$ meses e a atividade laboral relacionada à alimentação apresentaram significância estatística $(p=000$ e $p=0,003$ ) para o reganho ponderal. Conclusão: A cirurgia bariátrica promove redução adequada do excesso de peso corporal, com reganho ponderal significativo observado após cinco anos; o tempo pós-operatório, a atividade laboral estimulando alimentação fora de casa foram os fatores determinantes para a ocorrência do reganho de peso. 
O besity has emerged as a public health problem in recent decades because it is chronic, multifactorial, related to the high mortality rate and that, epidemiologically, presents alarming proportions ${ }^{1}$. In Brazil, overweight and obesity are increasing in the last 25 years, according to the Ministry of Health - VIGITEL Brasil ${ }^{20}$ (Surveillance of Risk and Protective Factors for Chronic Diseases Telephone Survey) the frequency of obese adults is $15 \%$.

Obesity is associated with increased rates of comorbidities such as type 2 diabetes mellitus, hypertension, dyslipidemia, coronary artery disease, among others. Furthermore, directly interferes with quality of life individual ${ }^{1}$. The main pillars for the treatment of obesity are dietary counseling, the practice of physical activity and pharmacological treatment. However, in severe cases conventional treatment does not produce satisfactory results, with $95 \%$ of individuals recovering their initial weight within two years ${ }^{1,37}$.

In this context, bariatric surgery has been identified as the only treatment to achieve adequate weight loss and durable ${ }^{21}$. The surgical procedure using mixed techniques is the gold standard of operations for severe obesity. The most used is the derivation gastrojejunal Roux-en-Y (DGYR) also known as gastric bypass, proposed by Fobbi and Capella7, ${ }^{15}$. DGYR results confirm its effectiveness in weight loss, as they relate to the reduction of comorbidities and improved quality of life $^{25}$. This technique displays some of the most consistent results in long-term ${ }^{5,9}$.

The DGYR induces an average loss of 60 to $75 \%$ of excess body weight, with the maximum loss over the period between 18 and 24 months postoperatively. However, several studies show that certain regained weight occurs from two years after the operation ${ }^{9,18.19}$.

Several risk factors are predictive for the occurrence of regained weight, such as poor eating habits, gastric pouch dilatation, reduced physical activity and hormonal adaptations ${ }^{18,29}$. The way the set of factors related to the weight loss process interact that determines the results of the operation on the body weight in the short and long-term ${ }^{21}$.

This explains the importance of prior knowledge of these factors in order to clarify the user as to the risks and possible critical periods of weight regain, and the possibility of return of comorbidities resulting from this process.

Thus, this study aims to identify the determinants of weight regained in patients undergoing bariatric surgery.
This study was approved by the Ethics and Research / CEP / UFAL with Case 012298/2011-11. Individuals were invited to participate and after due clarification and being in agreement, signed the consent form.

This is a prospective cross-sectional study involving 64 adults of both sexes, inserted in Bariatric Surgery Program of the University Hospital Professor Alberto Antunes, undergoing DGYR with time after surgery over two years. We excluded users who had surgical complications in the immediate postoperative period, pregnancy, cancer deaths, apart from individuals not located and those who disagreed to participate.

The subjects were divided into two groups (group I and group II), according to weight regain significant or not, each with 18 and 46 components, respectively.

Data were collected during outpatient nutrition through the records and meetings of the Support Group for Morbid Obese Patient, from September 2011 to January 2012. To contact users have scheduled this period or absent monitoring, active search was conducted by phone. Among a universe of 202 patients, 82 were not located, 26 became pregnant, six lived in other states, four died, two had complications postoperatively, 14 did not attend the scheduled interview, seven refused to participate in the study and one was excluded because has a diagnosis of cancer, totaling 142 exclusions.

It was collected the following variables: age, sex, education, economic class, work activity related to food, time after surgery, BMI, percentage of excess weight loss (\% EWL), weight gain, nutritional counseling attendance in style life, eating habits, perception of appetite, daily use of nutritional supplements and quality of life.

Schooling was investigated by levels of study, classified as: elementary (complete and incomplete), high school (complete and incomplete) and college (complete and incomplete). The economy class was investigated by the Economic Classification Criterion Brazil (OSCC) ${ }^{2}$. The labor activity corresponds to the current occupation of the individual, checking features related to food production.

The PEP\% is the percent of the weight lost in relation to overweight. Weight loss is considered one of the main parameters to define the success of the operation, and consensus among researchers that the criteria for this review is the \% EWL at least $50 \%$, with weight maintenance after long periods ${ }^{37}$. This percentage was based on the weight recorded on the day of the operation, ideal weight and minimum weight achieved after surgery, as described by Novais ${ }^{21}$. The ideal weight was calculated as proposed by $\mathrm{FAO}^{7}$, using the formula Ideal weight $=$ height $^{2} \mathrm{x}$ 
average $\mathrm{BMI}$, and average $\mathrm{BMI}=22$ for men and for women $=20.8$. BMI classification corresponded to the criteria established by the World Health².

For the evaluation of weight gain were considered the weight in the operation, the minimum weight achieved postoperatively and current weight, the latter two parameters used to calculate the percentage of weight regained. It was established cutoff of $15 \%$ as described by Odom et al. ${ }^{22}$ to indicate the occurrence of weight regain significant.

The evaluation of attendance at follow-up was related to the presence in the outpatient nutrition. The lifestyle was investigated considering the physical activity, alcohol and tobacco.

Dietary habits were assessed by questionnaire application Habitual Food Day with subsequent qualitative assessment of consumption of food groups, according to the orientation of the Food Pyramid. Appetite was assessed according to the individual's self-perception in reduced appetite, unchanged or increased. Was investigated the daily use of nutritional supplements prescribed, according to the protocol of nutritional monitoring postoperatively.

The quality of life was assessed by applying the "Questionnaire on quality of life, self-esteem and levels of activity," adapted from "Bariatric Analysis and Reporting Outcome System (BAROS) ${ }^{23}$, which defines score according to the evaluation of five issues in respective areas: self-esteem, physical, social, labor and sexual interest. The questionnaire results in groups of five ratings of quality of life can be greatly reduced, decreased, minimum / unchanged or improved greatly improved.

\section{Statistical Analysis}

For statistical analysis, the data were tabulated on Microsoft Office Excel 2007 version. The descriptive and inferential analysis was performed with the aid of the Statistical Package for the Social Sciences, version 18.0 ( SPSS Inc, Chicago, IL, USA ). Initially we tested the adherence of the data to the normal parameters , by means of Kolmogorov- Smirnov and Levene. Then we used the nonparametric Mann -Whitney test for variables time and \% PEP operated. The $t$ test for independent samples was variable: weight in operation, the IMC operation, minimum weight, period of lower weight, BMI and BMI threshold current for comparison of means between groups. To investigate the association between weight regain and the variables \% PEP, preoperative BMI, physical activity, socioeconomic class, labor activity, BAROS , alcoholism, supplementation, perception of appetite and nutritional counseling in attendance, we used the chi -square and odds ratio for a confidence interval of $95 \%(95 \%)$. In all cases, differences or associations were considered statistically significant when $p<0.05$.
RESULTS

It was evaluated 57 (89\%) women and seven (11\%) men, average age of $41.76 \pm 7.93$ years and duration of postoperative average of $53.4 \pm$ 18.4 months. Regarding education, 23 (36\%) had complete and incomplete elementary school, 27 (42.2\%) complete and incomplete high school and $14(21.8 \%)$ completed and incomplete college.

The evaluation of the economic classification showed that 28 patients $(43.75 \%)$ belonged to classes A and B, while $36(56.25 \%)$ were placed in classes $C$ and $D$, with no individual belonging to the class E. It was observed in this group average of 3.39 \pm 1.3 members per family.

Regarding labor activity, 53 (82.8\%) reported having no relation to food production, while 11 (17.1\%) reported working in activities such as lunch box, baker, owner of buffet / snack bar / grocery store or employees cafeteria.

As for anthropometry, average weight and BMI were: $127.48 \pm 24.2 \mathrm{~kg}$ and $49.56 \pm 6.7 \mathrm{~kg} / \mathrm{m}^{2}$ at the time of operation. The minimum weight achieved was $73.0 \pm$ $18.6 \mathrm{~kg}$, which corresponded to an average BMI of 28.3 $\pm 5.5 \mathrm{~kg} / \mathrm{m}^{2}$ in the time period of $23.7 \pm 12$ months postoperatively. Therefore, a reduction of $42.9 \%$ in BMI. The mean \% EWL was $75.9 \pm 15 \%$, observing weight loss until the second postoperative year.

The regained significant weight occurred in $18(28.1 \%)$ cases, while 46 (71.9\%) had no such condition. The characteristics related to weight gain are shown in Table 1.

It was observed that the weight regain was directly proportional to the time after surgery, showing a highly significant $(p=0.000)$. In relation to the BMI, it is able to reach the minimum, both groups remained in the range of overweight, whereas a BMI current was indicative of mild obesity.

Verifying the association between weight regain and possible contributing factors, there was a significant relation to the work activity related to food ( $p=0.003$ - Table 2).

TABLE 1 - Evolution of subjects undergoing weight DGYR according to the occurrence of regained weight

\begin{tabular}{|c|c|c|c|c|}
\hline Variables & $\begin{array}{c}\text { Group Ia } \\
(n=18)\end{array}$ & $\begin{array}{c}\text { Group IIa } \\
(n=46)\end{array}$ & $\begin{array}{l}\text { Total } \\
(n=64)\end{array}$ & $p$ \\
\hline Operated time ${ }^{2}$ & $66 \pm 8,3$ & $48,2 \pm 15,9$ & $53,4 \pm 18,4$ & $0,000^{1}$ \\
\hline $\begin{array}{l}\text { Weight in } \\
\text { operationc }\end{array}$ & $127,7 \pm 30,6$ & $127,3 \pm 21,6$ & 24,2 & $0,538^{2}$ \\
\hline BMI in operationd & $49,3 \pm 7,2$ & $49,6 \pm 6,6$ & $49,5 \pm 6,7$ & $0,528^{2}$ \\
\hline Minimum weightc & $72,1 \pm 24$ & $73,41 \pm 16,3$ & $73,0 \pm 18,6$ & $0,381^{2}$ \\
\hline $\begin{array}{l}\text { Period of lower } \\
\text { weightb }\end{array}$ & $18,1 \pm 6,7$ & $25,9 \pm 12,9$ & 12,0 & $0,010^{2}$ \\
\hline BMI minimumd & $27,5 \pm 5,6$ & $28,6 \pm 5,5$ & $28,3 \pm 5,5$ & $0,470^{2}$ \\
\hline$\%$ PEP & $77,9 \pm 14,8$ & $75,2 \pm 15,1$ & $75,9 \pm 15,0$ & 0,6091 \\
\hline Current BMId & $34,6 \pm 7,3$ & $30,1 \pm 5,7$ & $31,4 \pm 6,5$ & $0,007^{2}$ \\
\hline
\end{tabular}

${ }^{1} \mathrm{~T}$ Test, ${ }^{2}$ Mann-Whitney; ${ }^{3}$ average \pm standard deviation; ${ }^{\mathrm{b}}$ period in months; weight in $\mathrm{kg} ;{ }^{\mathrm{d}} \mathrm{IMC}$ in $\mathrm{kg} / \mathrm{m}^{2}$ 
TABLE 2 - Analysis of the factors related to the regained weight of subjects undergoing DGYR

\begin{tabular}{|c|c|c|c|c|c|}
\hline \multirow{2}{*}{ Variable } & \multirow{2}{*}{ Categories } & \multicolumn{2}{|c|}{ Groups } & \multirow{2}{*}{$\frac{\text { OR }}{\text { (IC95\%) }}$} & \multirow{2}{*}{$\mathrm{p}^{2}$} \\
\hline & & I & II & & \\
\hline \multirow{2}{*}{ \%PEP } & $<50$ & $1(25,0)$ & $3(75,0)$ & 1,11 & \multirow{2}{*}{0,707} \\
\hline & $\geq 50$ & $16(27,1)$ & $43(72,9)$ & $(0,10-11,52)$ & \\
\hline \multirow{2}{*}{$\begin{array}{c}\text { Preoperative } \\
\text { BMI }\end{array}$} & 40 a $50 \mathrm{~kg} / \mathrm{m}^{2}$ & $4(18,2)$ & $18(81,8)$ & 2,08 & \multirow{2}{*}{0,198} \\
\hline & $>50 \mathrm{~kg} / \mathrm{m}^{2}$ & $13(31,7)$ & $28(68,3)$ & $(0,58-7,42)$ & \\
\hline \multirow{2}{*}{ Physical activity } & Yes & $10(41,7)$ & $14(58,3)$ & 0,36 & \multirow{2}{*}{0,075} \\
\hline & No & $7(20,6)$ & $27(79,4)$ & $(0,11-1,16)$ & \\
\hline \multirow{2}{*}{ Economy class $^{1}$} & $A$ e $B$ & $9(25,7)$ & $26(74,3)$ & 1,15 & \multirow{2}{*}{0,511} \\
\hline & $C, D$ e E & $8(28,6)$ & $20(71,4)$ & $(0,37-3,53)$ & \\
\hline \multirow{2}{*}{ Woks with food } & Yes & $7(70,0)$ & $3(30,0)$ & 0,1 & \multirow{2}{*}{0,003} \\
\hline & No & $10(18,9)$ & $43(81,1)$ & $(0,02-0,45)$ & \\
\hline \multirow{2}{*}{ BAROS } & $\mathrm{Me} / \mathrm{Mme}$ & $1(33,3)$ & $2(66,7)$ & 0,72 & \multirow{2}{*}{0,618} \\
\hline & M/Nalt & $16(26,7)$ & $44(73,3)$ & $(0,06-8,57)$ & \\
\hline \multirow{2}{*}{ Alcoholism } & No & $8(27,6)$ & $21(72,4)$ & 0,94 & \multirow{2}{*}{0,572} \\
\hline & Yes & $9(26,5)$ & $25(73,5)$ & $(0,31-2,88)$ & \\
\hline \multirow{2}{*}{ Supplementation } & Yes & $7(43,8)$ & $9(56,3)$ & 0,34 & \multirow{2}{*}{0,08} \\
\hline & No & $10(21,3)$ & $37(78,7)$ & $(0,10-1,16)$ & \\
\hline \multirow{2}{*}{ Appetite } & Raised & $4(20,0)$ & $16(80,0)$ & 1,73 & \multirow{2}{*}{0,297} \\
\hline & Inalt/Reduced & $13(30,2)$ & $30(69,8)$ & $(0,48-6,19)$ & \\
\hline \multirow{2}{*}{$\begin{array}{l}\text { Nutritional } \\
\text { monitoring }\end{array}$} & Yes & $11(23,4)$ & $36(76,6)$ & 2,54 & \multirow{2}{*}{0,110} \\
\hline & No & $7(43,8)$ & $9(56,3)$ & $(0,76-8,42)$ & \\
\hline
\end{tabular}

M / Malt: minimal or no change, I / Mme: improved or much improved; Inalt / Reduced: unchanged or reduced; ${ }^{1}$ According to the classification of the Brazilian Association of Research; ${ }^{2}$ According to the Chi Square, OR: odds Ratio 95\% CI: $95 \%$

Considering the cutoff point on the\% EWL, indicative of surgical success, there was no significant difference between groups. Likewise, individuals with higher rates of BMI preoperatively showed no significant difference in the weight regain.

As for physical activity, 34 (53.1\%) individuals reported regular practice. Smoking was confirmed by two (3.1\%) and social drinking was reported by 29 (45.3\%).

The BAROS indicated that 61 (95.3\%) individuals had the quality of life improved or much improved, while only three (4.6\%) reported minimal change or no change.

The daily use of nutritional supplements was stated by 47 (73.4\%) patients, while 17 (26.5\%) reported irregular use or denied use, considering for this purpose multivitamin and mineral supplement. Regarding the perception of appetite, 44 (68.7\%) reported unchanged or reduced appetite, while 20 (31.2\%) reported an increase.
Dietary data revealed daily consumption of food sources of protein in all subjects, the foods cited: milk, meat, eggs, beans, chicken and fish. Regarding the group of vegetables, four (6.2\%) denied daily consumption, while $60(93.7 \%)$ stated that they used, and the vegetable soup preparation most cited. As for dairy, seven (10.9\%) reported never consuming. All daily consumed food sources of carbohydrates, especially type cracker biscuits and white bread.

In terms of attendance in nutrition, 16 (25\%) users were absent from scheduled appointments in the last year.

\section{DISCUSSION}

Severe obesity is prevalent in females. Program Surgery HUPAA looking great for the surgical treatment is given by women as a proportion of 5.7 women to a man ${ }^{26}$.

In women, weight control is strong motivation has important a esthetic and emotional components in food. In addition to predisposition to cardiovascular disease, obesity is associated with increased risk of breast cancer and endometrial cancer, polycystic ovaries and infertility ${ }^{2}$.

Results from research on nutrition and health involving low-income population in a county in Alagoas showed a prevalence of $22.7 \%$ of overweight / obesity in women ${ }^{28}$.

According Riobo et al. ${ }^{27}$, low socioeconomic status constitutes a risk factor for obesity, noting that the adult female population is exposed to high rates, even when the family income is below the absolute poverty line, ie with per capita income below $1 / 4$ minimum wage.

These data are corroborated by the $\mathrm{CCEB}^{2}$, this study identified that the majority of the population between classes $C$ and $D$, ie, with an average family income between R \$1,194.53 and R \$ 484.97 for families consisting of, on average, three members. On the other hand, much of the population is middle-level education, some incomplete.

Schooling and economic class are factors that can be inferred as predisposing occupation with informal jobs. Moreover, the condition of severe obesity prior determinant of social exclusion, promoting greater quest for low-paying jobs or unemployment ${ }^{28}$.

The labor activity related to food is characteristic common to users seeking bariatric surgery. In 2011, cross-sectional study was conducted with 132 obese patients before surgery, and significant association between severe obesity and food-related work activities, present in $64 \%$ of individuals surveyed ${ }^{28}$.

It is important to point out that high frequency activity in search of income that involves the 
production and sale of food, provides free access to food, which constitutes another environmental factor triggering the weight regain, as observed in this group.

Regarding surgical treatment, it is considered successful if there is a loss of at least $50 \%$ of the excess weight at operation and the individual having a BMI outside the classification of obesity degree III $^{1}$. Some authors establish rating for successful post-operative agreement with the results on BMI and BMI $<30 \mathrm{~kg} / \mathrm{m}^{2}$ considered excellent result, between 30 and $35 \mathrm{~kg} / \mathrm{m}^{2}$, good result and $>35 \mathrm{~kg} /$ $\mathrm{m}^{2}$, or failure failure ${ }^{8,17}$. In this group, according to these parameters is observed surgical success.

According to $\mathrm{ABESO}^{1}$, and the parameter achieve surgical success, it is necessary to maintain the weight loss for five years, since after this period may fail to maintain the weight ${ }^{9,14,19}$. In the population studied, it was found that the group has regained significant weight mean postoperative 5.5 years.

Satisfactory results were reported by Christou et al. ${ }^{8}$ reported that initial PEP\% around 70.4 in patients followed for 16 years. Beleli ${ }^{5}$ evaluated patients who eliminated $75.69 \%$ of the excess weight in two years postoperatively, the average found in similar studies Fobi et al. ${ }^{14}$ found that mean weight loss of $70 \%$ after two years. In the present study, the mean \%EWL of $75.9 \%$ was found, confirming the reported studies.

However, maintenance of weight loss conditions recommended to ensure the surgical results are not always achieved, observing a certain degree of weight recovery from the period of minimum weight reached, which runs between 18 and 24 months after the operation ${ }^{18}$.

Christou et al. ${ }^{8}$, study evaluated in weight loss after 10 years, evidence has confirmed that significant weight gain occurs after 24 months of continuous operation, the result observed by Magro et al ${ }^{19}$. Noted that regained weight in about $50 \%$ of patients who underwent gastric bypass. Studies by Packeji et $\mathrm{al}^{24}$. and Dalcanale et $\mathrm{al}^{9}$. observed that $30.6 \%$ of users who underwent surgery had regained moderate weight. Beleli et al. ${ }^{5}$ in a similar study, found that $26 \%$ of patients had regained weight during the study period, a result consistent with this work.

It is important to note that the factor that defines the significance of the regained weight is impairment of health resulting from the return to obesity, with a risk of recurrence of comorbidity ${ }^{3}$. In a study by Magro ${ }^{19}$ patients recovered, on average, $8 \%$ of its lighter weight obtained during the postoperative period, without compromising the results and benefits of surgical treatment. Shah et al. ${ }^{29}$ in a review of 86 publications, showed that the percentage of weight regained is significant in the long term, being directly proportional to the risk of recurrence of obesity-related comorbidities. Nevertheless, the long-term mortality is still low, reaching about $3.1 \%{ }^{8.24}$.

This weight regain after surgery proves the concept that obesity is a chronic, progressive disease that has no cure and requires specific treatment and ongoing monitoring 5,21,24.

Several factors are identified as non-surgical predictors of weight gain in patients undergoing DGYR, including: physical inactivity, poor dietary habits, poor adherence to postoperative follow-up, very high initial BMI, among other ${ }^{10,18,22,29}$.

With regard to smoking and alcohol consumption, were noted higher frequencies of nonsmokers and non-drinkers. Satiety is a prominent feature of weight loss after gastric bypass and persists in patients with excellent results. Patients who recover large amounts of weight refer to similar food intake prior to operation ${ }^{8}$. Self-perception of individuals investigated, most are not referenced increased appetite, not being this factor significantly associated with weight regain.

In the investigation of dietary factors, there was food monotony, with preference for dietary sources of simple carbohydrates with high glycemic index, rather than vegetables and dairy products. In research conducted by Faria et al. ${ }^{11}$ was found that individuals who make meals with a high glycemic load also exhibit decreased weight loss during the postoperative period.

In a study with low-income community in the capital of Alagoas, Florencio et al. ${ }^{43}$ observed a similar situation for the population studied in obese women with eating habits suggestive of "hidden hunger", characterized by a lack of habit (or access) in relation to the consumption of vegetables and dairy products.

The consensus is that people undergoing bariatric surgery have quantitatively and qualitatively inadequate diet to meet nutritional needs. According to Caruso et al. ${ }^{13}$, supplementation and clinical monitoring are imperative to prevent malnutrition and deficiencies of several vitamins and minerals. Farias et al. ${ }^{12}$ claim that the use of nutritional supplement was probably a contributing factor to the reduced expression of micronutrient deficiencies noted in their study, recommending oral supplementation and nutritional monitoring in order to avoid long-term nutritional deficiencies. It is inferred in the present study, the absence monitoring with the multidisciplinary team may interfere with maintaining the use of supplementation. It was considerable lack of attendance at scheduled nutritional consultations, not being in this research evaluated the remaining consultations and meetings with the multidisciplinary team.

Even so, major improvement in quality of 
life was detected after DGYR. According to work done by Prevedello ${ }^{26}$, quality of life was excellent in $21.9 \%$ of patients, very good in $50 \%$ and good in $28.1 \%$. In the study by González et al ${ }^{16}$, with 31 patients undergoing gastric bypass over 12 months, according to the evaluation scores BAROS was excellent in $58.1 \%$, very good in $22.6 \%$, good in 16 , $1 \%$, and $3.2 \%$ acceptable, showing no evolution insufficient. Positive results were found in this study, according to the method BAROS.

The weight regain is undoubtedly a challenge faced by surgeons and by the multidisciplinary team in the late follow-up of patients undergoing bariatric surgical procedures, in particular the derivations gastrojejunal. The weight removed can be recovered if they are not made changes in lifestyle, daily habits and dietary practices. Other aspects such as adherence to treatment, psychological disorders, genetic predisposition, and the action of incretin gut flora may play a critical role in the process of loss or weight regain over the years.

\section{CONCLUSION}

Bariatric surgery promotes adequate reduction of excess body weight, with regained significant weight observed after five years, the postoperative time, labor activity stimulating eating out were the determining factors for the occurrence of weight regain.

\section{REFERENCES}

1. Associação Brasileira para o Estudo da Obesidade e da Síndrome Metabólica. Diretrizes brasileiras de obesidade 2009/2010 / ABESO - Associação Brasileira para o Estudo da Obesidade e da Síndrome Metabólica. - 3.ed. - Itapevi, SP : AC Farmacêutica, 2009.

2. Associação Brasileira de Empresas de Pesquisa (2008). Critério de Classificação Econômica Brasil. Disponível em: www.abep.org. Acesso em: Janeiro de 2012.

3. American Association of Clinical Endocrinologists, The Obesity Society, and American Society for Metabolic \& Bariatric Surgery Medical Guidelines for Clinical Practice for the Perioperative Nutritional, Metabolic, and Nonsurgical Support of the Bariatric Surgery Patient. AACE/TOS/ASMBS Guidelines. Elsevier and Surg Obes Relat Dis. 2008; 4:S109S184.

4. Barbosa, EMWG. Impacto de um programa de cirurgia bariátrica sobre o perfil metabólico e antropométrico de mulheres segundo diferentes classificações de obesidade. 2009. 148 fls. Dissertação (Mestrado em Nutrição Humana)Faculdade de Nutrição, Universi-dade Federal de Alagoas, 2009.

5. Beleli CAV, Filho AC, Silva RM, Camargo MA, Scopin DR. Fatores preditivos na perda ponderal de pacientes submetidos ao Bypass Gástrico em Y-de-Roux. Bariátrica e Metabólica Ibero-Americana 2011; 1:16-23.

6. Brolin RE.Weight gain after short-and-limb gastric bypass in patients followed for longer than 10 years. Ann Surg. 2007; 246 (1):163-4.
7. Capella JF, Capella RF. Vertical banded gastroplasty-gastric bypass: preliminary report. Obes Surg, 1991, I(4): 389-395.

8. Christou N V, Look D, Mac Lean LD. Weight gain after short and long limb gastric bypass in patients followed for longer than 10 years. Ann Surg . 2006; 244; 734-9.

9. Dalcanale L, Oliveira CPMS, Faintuch J, Nogueira MA, Rondó P, Lima VMRL, Mendonça S, Pajecki D, Mancini M, Carrilho FJ. Long-Term Nutritional Outcome After Gastric Bypass. Obes Surg. 2010; 20:181-187.

10.Elfhag K \& Rössner S. Who succeeds in maintaining weight loss? A conceptual review of factors associated with weightloss maintenance and weight regain. The International Association for the Study of Obesity. Obesity Reviews 6, 67-85, 2005.

11.Faria SL, Faria OP, Lopes TC, Galvão MV, Kelly EO, Ito MK. Relation between carbohydrate intake and weight loss after bariatric surgery, Obes Surg 2009; 19:708 -71.

12. Farias LM, Coelho MPSS, Barbosa RF, Santos GS, Marreiro DN. Aspectos nutricionais em mulheres obesas submetidas à gastroplastia vertical com derivação gastro-jejunal em Y-deRoux. Rev Bras Nutr Clin 2006; 21(2):98-103.

13. Florêncio TMMT, Ferreira HS, Cavalcante CC, Luciano SCM, Sawaya AL. Food consumed does not account for the higher prevalence of obesity among stunted adults in a very low income population in the Northeast of Brazil (Maceió, Alagoas). European Journal of Clinical Nutrition, England 2003:57 (11); 1437-46.

14.Fobi MA, Lee - The surgical techinique of the banded Roux-en-Y gastric bypass. J Obes Weight Regulation 1989; 8:99-102. In: Valezi AC, Mali Júnior J, Brito EM, Marson AC. Gastroplastia vertical com bandagem em Y- de- roux: análise de resultados. Rev Col Bras Cir 2004; 31(1):49-56.

15. Fobi MA. Surgical treatment of obesity: a review. J Natl Med Assoc. 2004;96(1):61-75.

16.González JF, Gómez G, Arraigada G. Evaluación mediante score Baros de los resultados del bypass gástrico en el tratamiento de la obesidad mórbida. Rev Chilena Cir. 2006;58:365-70.

17.Gumbs AA, Pomp A, Gagner M. Revisional bariatric surgery for inadequate weight loss. Obes Surg. 2007;17(9):1137-45.

18.Lopez PP, Patel NA, Koche LS. Outpatient complications encountered following Roux-en-Y gastric bypass. Med Clin North Am. 2007;91:471-83.

19.Magro DO, Delfini R, Pareja BC, Callejas F, Pareja JC. Longterm Weight Regain after Gastric Bypass: A 5-year Prospective Study. Obes Surg 2008; 18:648-651.

20.Ministério da Saúde. Vigitel Brasil 2010: vigilância de fatores de risco e proteção para doenças crônicas por inquérito telefônico / Ministério da Saúde, Secretaria de Vigilância em Saúde, Secretaria de Gestão Estratégica e Participativa. Brasília: 2011.

21.Novais PFS, Junior IR, Leite CVS, Oliveira MRM. Evolução e classificação do peso corporal em relação aos resultados da cirurgia bariátrica - derivação gástrica em Y-de-Roux. Arq Bras Endocrinol Metab. 2010;54(3):303-10.

22.Odom J, Zalesin KC, Washington TL et al. Behavioral Predictors of Weight Regain after Bariatric Surgery. OBES SURG 2010; 20:349-356.

23.Oria $\mathrm{HE}$, Moorehead MK. Bariatric analysis and reporting outcome system (BAROS). Obes Surg. 1998;8:487-99.

24.Pajecki D, Dalcanalle L, Oliveira CPS, Zilberstein B, Halpern A, GarridoAB, Cecconello I. Follow-up of Roux-en-Y gastric bypass patients at 5 or more years postoperatively. Obes Surg. 2007;17:601-7.

25.Pedrosa IV, Burgos MGPA, Souza NC, Morais CN. Aspectos nutricionais em obesos antes e após a cirurgia bariátrica. Rev Col Bras Cir. 2009; 36(4).

26.Prevedello CF, Colpo E, Mayer ET, Copetti H. Análise do impacto da cirurgia bariátrica em uma população do centro do estado do Rio Grande do Sul utilizando o método BAROS. Arq Gastroenterol. 2009; 46 (3): 199-203. 
27.Riobó P, Bobadilla BF, Kozarcewski JM, Moya JMF. Obesidad en la mujer. Nutr Hosp 2003; 18 (5): 233-237.

28. Rocha HM, Oliveira TT, Barbosa EMWG, Oliveira AC. Interface entre obesos severos e atividade laboral relacionada a alimentos. Iniciação Científica CESUMAR 2011; 13 (1): 75-80

29.Shah M, Simha V, Garg A. Review: Long term impact of bariatric surgery on body weight, comorbidities, and nutritional status. J. Clin. Endocrinol. Metab.2006; 91: 42234231.
30.World Health Organization, Obesity and overweight. Disponível em: www.who.int/dietphysicalactivity/ publications/facts/obesity. Acessado em: Janeiro, 2012. 